\title{
Vertical distribution of the prokaryotic cell size in the Mediterranean Sea
}

\author{
R. La Ferla • G. Maimone • M. Azzaro • \\ F. Conversano $\cdot$ C. Brunet $\cdot$ A. S. Cabral . \\ R. Paranhos
}

Received: 28 July 2011/Revised: 29 January 2012/ Accepted: 27 February 2012/Published online: 16 March 2012

(C) Springer-Verlag and AWI 2012

\begin{abstract}
Distributions of prokaryotic cell size and morphology were studied in different areas of the Mediterranean Sea by using image analysis on samples collected from surface down to bathypelagic layers (max depth 4,900 m) in the Southern Tyrrhenian, Southern Adriatic and Eastern Mediterranean Seas. Distribution of cell size of prokaryotes in marine ecosystem is very often not considered, which makes our study first in the context of prokaryotic ecology. In the deep Mediterranean layers, an usually-not-considered form of carbon sequestration through prokaryotic cells has been highlighted, which is consistent with an increase in cell size with the depth of the water column. A wide range in prokaryotic cell volumes was observed (between 0.045 and $0.566 \mu \mathrm{m}^{3}$ ). Increase in cell size with depth was opposed to cell abundance distribution. Our results from microscopic observations were confirmed by the increasing HNA/LNA ratio (HNA, cells with high nucleic acid content; LNA, cells with low nucleic acid content) along the water column. Implications of our results on the increasing cell size with depth are in the fact that the quantitative estimation of prokaryotic biomass
\end{abstract}

Communicated by Heinz-Dieter Franke.

R. La Ferla $(\varangle) \cdot$ G. Maimone · M. Azzaro

Istituto per l'Ambiente Marino Costiero, IAMC-CNR,

Spianata S. Raineri 82, 98122 Messina, Italy

e-mail: rosabruna.laferla@iamc.cnr.it

F. Conversano - C. Brunet

Stazione Zoologica A. Dohrn, Villa Comunale,

80121 Naples, Italy

A. S. Cabral · R. Paranhos

Instituto de Biologia, Universidade Federal do Rio de Janeiro,

UFRJ, Av. Prof. Rodolfo Rocco 211, Ilha da Fundão,

Rio de Janeiro, Brazil changes along the water column and the amount of carbon sequestered in the deep biota is enhanced.

Keywords Prokaryotic sizes - Prokaryotic morphotypes · Vertical distribution - Cell carbon content - Image analysis . Mediterranean Sea

\section{Introduction}

Marine microbial biomass and metabolism as well as its role on oceanic $\mathrm{C}$ pump are focal points in marine ecology studies. In this frame, prokaryotic biomass quantification (both bacteria and archaea) is a key parameter for the knowledge of food-web functioning and the cycling of organic matter or nutrients in the context of oceanic biogeochemical fluxes (Fukuda et al. 1998; Tanaka and Rassoulzadegan 2002).

The relevant role of prokaryotes in the water column has been recently assessed, and new concepts on the functioning of this community have been developed mainly about the importance of prokaryotes in the dark water column (Arístegui et al. 2009; Nagata et al. 2010; Reinthaler et al. 2006).

Biomass of prokaryotic natural assemblages in aquatic environment is mainly investigated by cell countingusing epifluorescence microscopy or flow cytometry. Then, a conversion factor is applied for transforming cell number into carbon content in order to estimate biomass. The relationship between cell and dry mass has been determined by several methods to establish the appropriate conversion factors, as referred by Pernthaler and Amann (2005), and the most frequently applied conversion factor derives from the assumption that each marine bacterium contains 20 fg of carbon (Ducklow and Carlson 1992; Lee 
and Fuhrman 1987). Nevertheless, since the cell carbon content varies together with cell volume (Bölter et al. 2002; Fukuda et al. 1998), the use of a constant conversion factor might determine an overestimation or underestimation of the actual standing stock. As a consequence, the determination of size is needed to accurately estimate prokaryote biomass. Size is one of the most relevant ecological traits, and the understanding of the mechanisms controlling size distribution is crucial for revealing the interaction of the prokaryotes with their environment. The importance of prokaryotic cell size has been discussed in-depth by Young (2006), stating the selective biological implication of cell shapes. Among the phenotypic traits of microbial communities, size reflects the complexity of the habitats at microscale and, in some extent, the distribution patterns of different genotypes (Pernthaler and Amann 2005). Specific studies on size distribution and size classification are very rare and, among them, Bölter et al. (1993) is concerned about the methodological comparisons between different data treatments applied to soil bacteria.

Several studies have been carried out on the size spectra of natural population of prokaryotes in aquatic environment (Rassoulzadegan and Sheldon 1986; Posch et al. 2009), but relatively few studies have so far dealt with the cell size and morphotypes in relation with environmental parameters (Jochem 2001; Robarts et al. 1996). This has been done mainly at regional scale (Mahadevaswamy et al. 2008; Zmuda 2005) or in relation with protistan grazing pressure (Pernthaler et al. 1996; Simek et al. 2001).

Recent studies have shown that prokaryotic cell size often increases with depth in the water column (La Ferla et al. 2010; Van Wambeke et al. 2010) even though the interpretation is still unknown. Cell size is the result of the balance between different factors, among which are resource availability, cell growth, frequency of division (Tanaka and Rassoulzadegan 2002), bacteriovory (Pernthaler 2005), viral lysis (Danovaro et al. 2008) and species composition (Jochem 2001). Environmental characteristics, such as hydrostatic pressure (Grossart and Gust 2009), turbulence (Peters et al. 2002), temperature and chemical variables (Kalcheva et al. 2008), also are able constraining cell size variations.

Information on prokaryotic biomass depends on the methodology used for the study. Indeed, epifluorescence microscopy differentiates prokaryotic morphotypes and subpopulations with different sizes and carbon content (Jochem 2001), while the application of flow cytometry distinguishes sub-populations with a different apparent DNA content (Button and Robertson 2001). Differences in the side scatter signal (SSC, related to the size, density and morphology of the cells) and in the relative green fluorescence (related to the nucleic acid content of the cells) allow discriminating two fractions, named HNA cells (cells with high nucleic acid content) and LNA cells (cells with low nucleic acid content) (Gasol and del Giorgio 2000). The HNA cells are generally considered to represent active members of the bacterial community, whereas LNA may be dead or dying cells (Gasol et al. 1999; Lebaron et al. 2002). However, the use of HNA cell abundance as a proxy for the activity in natural systems has been questioned (Bouvier et al. 2007; Moran et al. 2007). As stressed by different studies (Felip et al. 2007; Gasol et al. 1999), using both epifluorescence microscopy and flow cytometry allows us to deeply investigate the distribution patterns of prokaryotic cell volumes.

In coastal and pelagic areas of the Mediterranean Sea (MED), results on prokaryotic volumetric determinations have been already obtained (e.g., La Ferla and Leonardi 2005; Misic et al. 2008; Pedrós-Alió et al. 1999; La Ferla et al. 2010). In the MED, flow cytometry has been used mainly to study phototrophic organisms (Casotti et al. 2003), to analyze prokaryotes of fresh sediments (Amalfitano et al. 2009; Fazi et al. 2008) or to monitor living properties of bacterial cells (Caruso et al. 2010; Scharek and Latasa 2007).

Our general aim is to investigate the prokaryotic cell volume and morphology variations in the MED on a vertical scale as a first step in understanding the microbial structures and their ecological functions in this marine environment. The specific goals of this study are (1) to investigate the size distribution of the prokaryotic cells with depth in different Mediterranean pelagic ecosystems and (2) to understand the relationship between environmental properties and cell size distribution in order to look for the main driving forcing of cell size distribution.

For this purpose, we applied image analysis equipped with epifluorescence microscopy for cell determinations together with flow cytometry analysis along the water column of several stations from the South Tyrrhenian (ST), South Adriatic (SA) and Eastern Mediterranean (EM) Seas.

\section{Materials and methods}

In the frame of several oceanographic projects carried out in MED, different pelagic sites are sampled from surface to bottom (Fig. 1). In particular, in the framework of the Italian VECTOR project, seawater samples are collected from a station in the South Adriatic Sea (SA: AM1 stn., in June 2009) and four stations in the South Tyrrhenian Sea (ST: VTM-09, in February 2009, VTM-10, VTM1-10 and VTM5-10 stns., in February 2010). In the framework of 
Fig. 1 Map of the sampling areas. Black circles points to sampling stations

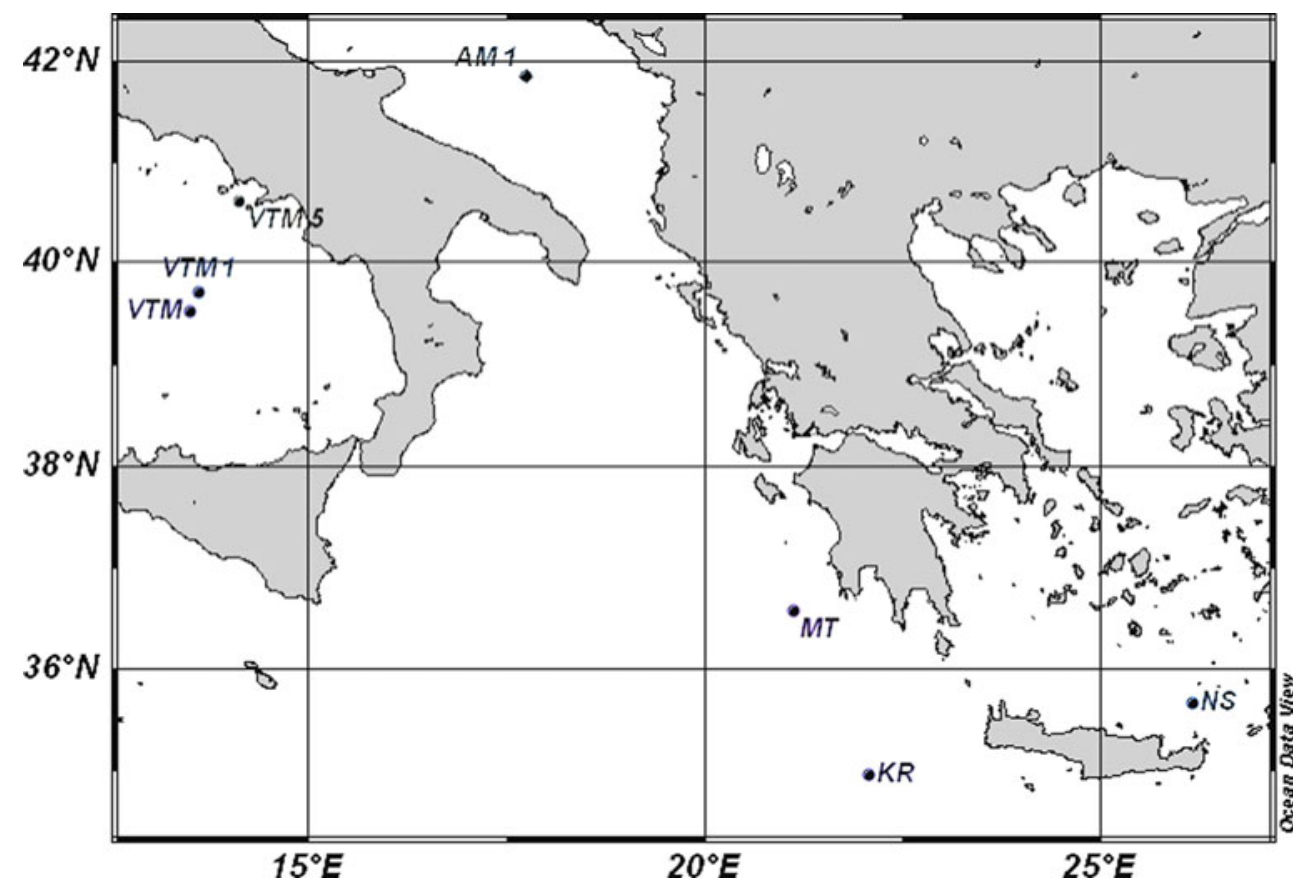

MIDDLE project-devoted to the study of the Anoxic Basins (BAMO) of the Eastern MED (EM) - three stations are sampled in June 2010 in the oxygenated water column above the basins: Matapan (MT), NewSS11 (NS) and Kryos (KR). The oceanographic cruise in the SA is performed aboard the R/V Universitatis of the National Interuniversity Consortium for Marine Sciences (CoNISMa); all the other cruises are performed aboard the R/V Urania of the Italian National Research Council (CNR). All the surveys have similar sampling strategies and methodologies. In all studied sites, almost the same depths are sampled $(5,10$, $25,50,75,100,200,300,500,750,1,000,1,500,2,000$, 2,500, 3,000, 3,500, 4,000, 4,500 and 4,900 $\mathrm{m}$ ) according to the bathymetry. The dates, coordinates and bottom depths of the sampling stations are reported together with the sample ranges, names of the cruise and projects (Table 1).

Hydrological parameters and dissolved oxygen

CTD casts are performed using a calibrated Sea Bird Electronics SBE 9/11 PLUS coupled to a Carousel SBE 32 of 12/24 Niskin bottles. The CTD probe is equipped with oxygen, fluorometer and transmissometer sensors. Calibration of temperature and conductivity sensors is performed at the SACLANT Research Center (La Spezia, Italy) before cruises.

Parallel determination of oxygen concentration is carried out at all the sampling depths using the Winkler method (Carpenter 1965) with an automatic endpoint detection burette Metrohm 716 DNS Titrino.
Nutrient concentrations and photosynthetic pigments

Samples for determining nutrient concentrations are collected in $20-\mathrm{mL}$ polyethylene vials and quickly frozen and stored at $-20^{\circ} \mathrm{C}$. Nutrient concentrations are determined within a few weeks after the end of each cruise, using a hybrid Brän-Luebbe-Technicon AutoAnalyzer following classical methods (Grasshoff 1976) with slight modifications. In brief, flow rates of reagents are reduced, and their concentrations changed to obtain the same quantity of reagents in the mixed flow though reducing the dilution of the sample and thus increasing the sensitivity by a factor of two. All nutrient concentrations are determined using running standards for each batch (in general two or three stations). All samples are analyzed twice, and all the analyses are carried out with the same setup of equipment.

For photosynthetic pigments, $3 \mathrm{~L}$ samples are filtered onto Nuclepore filters ( $47 \mathrm{~mm}$ diameter) of $3 \mu \mathrm{m}$ porosity and onto Nuclepore filters ( $47 \mathrm{~mm}$ diameter) of $0.2 \mu \mathrm{m}$ porosity, separating the picophytoplankton fraction from the rest of the community (micro- and nano-phytoplankton). Filters are immediately stored in liquid nitrogen for later pigment analysis. High-performance liquid chromatography (HPLC) analyses are performed within 2 weeks of collection according to the protocol described in Dimier et al. (2007). Briefly, pigment filters are extracted in $5 \mathrm{~mL}$ $100 \%$ methanol, and $500 \mathrm{~mL}$ of $1 \mathrm{~mol} \mathrm{~L}^{1}$ ammonium acetate is added to the $1 \mathrm{~mL}$ pigment extract for five minutes before the analysis in a Hewlett-Packard series 1100 HPLC (Hewlett-Packard, Wilmington, NC, USA). A 3-mm C8 BDS column (ThermoHypersil, Runcorn, UK) 
Table 1 Sampling stations, dates, coordinates, bottom depths, sample numbers, names of cruise and projects

\begin{tabular}{lllllll}
\hline & Date & Coordinates & $\begin{array}{l}\text { Depth } \\
(\mathrm{m})\end{array}$ & $\begin{array}{l}\text { Sample } \\
\text { numbers }\end{array}$ & Cruise & Project \\
\hline AM1 & June 2008 & $41^{\circ} 50^{\prime} \mathrm{N}, 17^{\circ} 45^{\prime} \mathrm{E}$ & 1,200 & 11 & AM 7 & VECTOR-Carpel.AM \\
VTM-09 & February 2009 & $39^{\circ} 30^{\prime} \mathrm{N}, 13^{\circ} 30^{\prime} \mathrm{E}$ & 3,500 & 13 & Vetimer 3 & VECTOR-Carpel.TM \\
VTM-10 & February 2010 & $39^{\circ} 30^{\prime} \mathrm{N}, 13^{\circ} 30^{\prime} \mathrm{E}$ & 3,500 & 16 & Vetimer 4 & VECTOR-Carpel.TM \\
VTM 5-10 & February 2010 & $40^{\circ} 36^{\prime} \mathrm{N}, 14^{\circ} 08^{\prime} \mathrm{E}$ & 688 & 5 & Vetimer 4 & VECTOR-Carpel.TM \\
VTM1-10 & February 2010 & $39^{\circ} 42^{\prime} \mathrm{N}, 13^{\circ} 37^{\prime} \mathrm{E}$ & 2,750 & 15 & Vetimer 4 & VECTOR-Carpel.TM \\
MT & June 2010 & $36^{\circ} 34^{\prime} \mathrm{N}, 21^{\circ} 07^{\prime} \mathrm{E}$ & 4,900 & 17 & Middle 2010 & MAMBA \\
NS & June 2010 & $35^{\circ} 39^{\prime} \mathrm{N}, 26^{\circ} 10^{\prime} \mathrm{E}$ & 2,270 & 14 & Middle 2010 & MAMBA \\
KR & June 2010 & $34^{\circ} 57^{\prime} \mathrm{N}, 22^{\circ} 05^{\prime} \mathrm{E}$ & 3,238 & 15 & Middle 2010 & MAMBA \\
\hline
\end{tabular}

is used, and the mobile phase is composed of a two-solvent mixture: A, methanol, aqueous ammonium acetate (70:30), and B, methanol. Pigments are detected at $440 \mathrm{~nm}$, and for each pigment, the absorption spectrum between 400 and $700 \mathrm{~nm}$ is done using a photodiode array detector (model DAD series 1100, Hewlett-Packard). Chlorophyll and derivatives also are analyzed by fluorometry (series 1100 fluorometer, Hewlett-Packard), using a $410 \mathrm{~nm}$ excitation wavelength and a $665 \mathrm{~nm}$ emission wavelength, and quantified using standards from the V.K.I. (Water Quality Institute, Horsholm, Denmark).

\section{Epifluorescent microscopy (Image analysis)}

Seawater samples for the prokaryotic abundance (PA) and size (VOL) determinations are directly collected in sterile condition in falcon tubes (polyethylene), immediately fixed with prefiltered formaldehyde $(0.2-\mu \mathrm{m}$ porosity; final conc. $2 \%$ ) and stored in the dark at $4{ }^{\circ} \mathrm{C}$ to prevent contamination till the laboratory treatment (within 10 days). Fixed samples are filtered onto black $0.22-\mu \mathrm{m}$-pore-size polycarbonate membranes. PA is determined by DAPI staining (Porter and Feig 1980) and enumerated by a Zeiss AXIOPLAN 2 Imaging (magnification: Plan-Neofluar $100 \times$ objective and $10 \times$ ocular) equipped with the digital camera AXIOCAM HR (Zeiss). The images are captured and digitized on a personal computer using the AXIOVISION 3.1 software for the subsequent morphometric analysis. The standard resolution of $1,300 \times 1,030$ pixels is used for the image acquisition. The pixel size in the resulting image is $0.106 \mu \mathrm{m}$ by automatic calibration. Further calibration is performed by measuring a FITC-dyed suspension of monosized latex beads (diameter, $2.13 \mu \mathrm{m}$ ). Thereafter, according to their morphology by an image analysis macro, the cells are simply classified into cocci (spherical cells), coccobacilli, rods (elongated cells), vibrios and spirillae (i.e., C-shaped and S-shaped cells, respectively). According to Lee and Fuhrman (1987), the pixels that constituted the fluorescent "halo" around the bacterial cells are not measured. The volume (VOL, expressed in $\mu \mathrm{m}^{3}$ ) is derived from the two-dimensional parameters (width, $W$, and length, $L$ ) obtained by image analysis, assuming that the cells are cylindrical straight rods with hemispherical or, in the case of coccoid forms, spherical caps (Massana et al. 1997). The volume of a single cell is calculated according to the geometrical formula (Krambeck et al. 1981):

$\operatorname{VOL}\left(\mu \mathrm{m}^{3}\right)=(\pi / 4) \cdot W^{2} \cdot(L-W / 3)$

For coccoid forms, $W=L$.

Measurements are taken on an adequate number of cells to obtain a well-representative mean volume due to normal distribution of the data.

An allometric relation is used in the calculation of the cell carbon content (CCC):

$\mathrm{CCC}\left(\mathrm{fg} \mathrm{C} \mathrm{cell}^{-1}\right)=218 \cdot \mathrm{VOL}^{0.86}$

This formula has been proposed by Loferer-Krößbacher et al. (1998) and routinely adopted for DAPI-stained cells in marine and limnetic environments (Posch et al. 2001), assuming that $80 \%$ of the biovolume consisted of water, while the other part of the dry weight $(20 \%)$ is considered to be constituted by $50 \%$ carbon (Bölter et al. 2006). Thereafter, the prokaryotic biomass (PB expressed in $\mu \mathrm{g} \mathrm{C}$ $\mathrm{L}^{-1}$ ) is calculated by multiplying the mean PA of each sample to the corresponding CCC derived from VOL.

Errors during biomass calculation by $\mathrm{PA}$ and VOL account for $>5 \%$ and $\sim 3 \%$, respectively, as already estimated by Bölter et al. (2002).

\section{Flow cytomery}

Samples for flow cytometry analysis are preserved by fixation with sterile $(0.22 \mu \mathrm{m}$ ) paraformaldehyde $2 \%$ (final concentration) for $15 \mathrm{~min}$ and freezing in liquid nitrogen. At the laboratory, samples are stained with Syto13 at $2.5 \mu \mathrm{M}$ (Gasol and del Giorgio 2000; Andrade et al. 2003). Counts $\left(\mathrm{PA}^{\mathrm{C}}\right)$ are performed in a CyAn ADP flow cytometer (Dako, USA) equipped with a solid-state laser (488 nm, $25 \mathrm{~mW}$ ) and filter modifications (green FL1 to $515 \pm 30 \mathrm{~nm}$ and red FL4 to $660 \pm 30 \mathrm{~nm}$ ). For 
calibration of side scatter and green fluorescence signals, and as an internal standard for cytometric counts, fluorescent latex beads (1.58 $\mu \mathrm{m}$ diameter) are systematically added. Based on optics and fluorescence signals, HNA and LNA cells abundances are also determined (Gasol and del Giorgio 2000).

\section{Data processing and statistical analyses}

Data are grouped according to the following depth intervals: >2-200 m (epipelagic layer), >200-1,000 m (mesopelagic layer) and $>1,000 \mathrm{~m}$-bottom depth (bathypelagic layer).

Descriptive statistical analysis and Pearson's correlations are performed with SigmaStat software v3.0, and analysis of variance (ANOVA) is applied to log-transformed VOL data to assess the statistical differences between sampling depths.

Multivariate analysis is performed using the package Primer 6 (Clarke and Gorley 2006). The Shannon index $\left(\mathrm{H}^{\prime}\right)$ applied on cell volume and specific morphological form data (cocci, coccobacilli, rods, vibrios and spirillae) is estimated for the different sampling depths. Hierarchical cluster analysis (HCA) is applied to test the similarity (group average linkage method) level of cell size versus depth as well as principal component analysis (PCA) to reduce the environmental variables down to a few components (Jolliffe 2005).

\section{Results}

\section{Environmental data}

In Fig. 2, depth profiles of potential temperature, salinity, potential density and nutrients are reported. Environmental properties of the three above-referred layers in the water column are reported in Table 2, in which the range of variations, median, mean and standard deviation for the physical, chemical and pigments characteristics are shown. Pigments are analyzed only in the first 120-m layer of the water column. Picophytoplankton accounts for the 66-97\% of the total Chla biomass revealing the strong oligotrophy of the sampled area.

\section{Microbiological parameters}

Microbiological results are reported in Table 3 for the three layers of the water column, showing the range of variations, median, mean and standard deviations of the following parameters: VOL (cell volume), CCC (cell carbon content), PA (prokaryotic abundance), PB (prokaryotic biomass), $\mathrm{PA}^{\mathrm{C}}$ (prokaryotic abundance by cytometry) and
HNA/LNA ratio (the ratio between high nucleic acid cells and low nucleic acid cells).

VOL, has a mean value of $0.222 \pm 0.111 \mu \mathrm{m}^{3}$, ranging between 0.045 and $0.566 \mu \mathrm{m}^{3}$. Its distribution with depth is shown in Fig. 3a. A large dispersion of VOL is found at both the photic and aphotic layers, while the mean volume is lower in epipelagic layer than in the meso- and bathypelagic ones, with the only exception of the uppermost layer. On a horizontal spatial scale, the mean cell volume varies over the different areas studied, with the smallest size occurring in SA (mean value, $0.15 \pm 0.07 \mu \mathrm{m}^{3}$ ), the intermediate in ST (mean value, $0.20 \pm 0.15 \mu^{3}$ ) and the highest in EM (mean value, $0.24 \pm 0.08 \mu \mathrm{m}^{3}$ ). The highest variability in VOL (higher standard deviation) is found at the ST stations. Seasonal scale does not affect the cell volume distribution, as revealed by the lack of significant difference between June and February (mean values of $0.21 \pm 0.15$ and $0.22 \pm 0.08 \mu \mathrm{m}^{3}$ in June and February, respectively). On an inter-annual scale, cell volume increases from 2008 to 2010 (mean of $0.15 \pm 0.07$; $0.17 \pm 0.07$ and $0.24 \pm 0.08$ in 2008, 2009 and 2010, respectively). Unfortunately, only two stations are sampled in 2008 and 2009 against six in 2010.

CCC dependent on cell volume varies in the range 15-129 fg C cell ${ }^{-1}$ with a mean value of $57 \pm 25 \mathrm{fg} \mathrm{C}$ cell $^{-1}$. Spatial variability of the distribution is high, with differences among the sampled areas (mean values of 39, 51 and $61 \mathrm{fg} \mathrm{C}^{-1}{ }^{-1}$ in SA, ST and EM, respectively, data not shown) and with depth.

On the contrary to cell size, PA presents the highest values in the euphotic layers and thus decreasing with depth (Fig. 3b). PA varies between 0.4 and $28.9 \times 10^{5}$ cells ml ${ }^{-1}$ with mean value of $4.7 \pm 3.1 \times 10^{5}$ cells ml $^{-1}$. PA is the lower in $\mathrm{EM}$ (mean value, $3.1 \pm 2.9 \times 10^{5} \mathrm{cells} \mathrm{ml}^{-1}$ ), relative to that in the ST (mean value, $5.2 \pm 6.3 \times$ $10^{5}$ cells ml $^{-1}$ ), and in SA (mean value, $6.1 \pm 4.2 \times 10^{5}$ cells $\mathrm{ml}^{-1}$ ).

$\mathrm{PB}$, ranging between 0.9 and $73.1 \mu \mathrm{g} \mathrm{C} \mathrm{L}^{-1}$ (mean value, $16 \pm 10 \mu \mathrm{g} \mathrm{C} \mathrm{L}^{-1}$ ), shows the highest values at surface and seems to be more dependent on PA than VOL. $\mathrm{PB}$ is higher in SA $\left(19 \pm 8 \mu \mathrm{g} \mathrm{C} \mathrm{L}^{-1}\right)$, than in EM $\left(17 \pm 13 \mu \mathrm{g} \mathrm{C} \mathrm{L}^{-1}\right)$ and ST $\left(14 \pm 16 \mu \mathrm{g} \mathrm{C} \mathrm{L}^{-1}\right)$. As for PA, PB presents the highest variability in the ST area.

The $\mathrm{PA}^{\mathrm{C}}$ distribution along the water column varies between 0.18 and $37.87 \times 10^{5}$ cells ml $^{-1}$, and it significantly correlates to PA $(r=0.32, n=106, P<0.01)$. $\mathrm{PA}^{\mathrm{C}}$ results underestimated relatively to $\mathrm{PA}$ (from image analysis) probably due to the weak fluorescence signal by smaller cells.

The HNA/LNA ratio ranges between 0.09 and 3.69 with the means of $0.64,1.32$ and 1.44 in the epi-, meso- and bathypelagic layers, respectively. These results suggest increasing bacterial sizes and cellular volumes toward deep waters. 

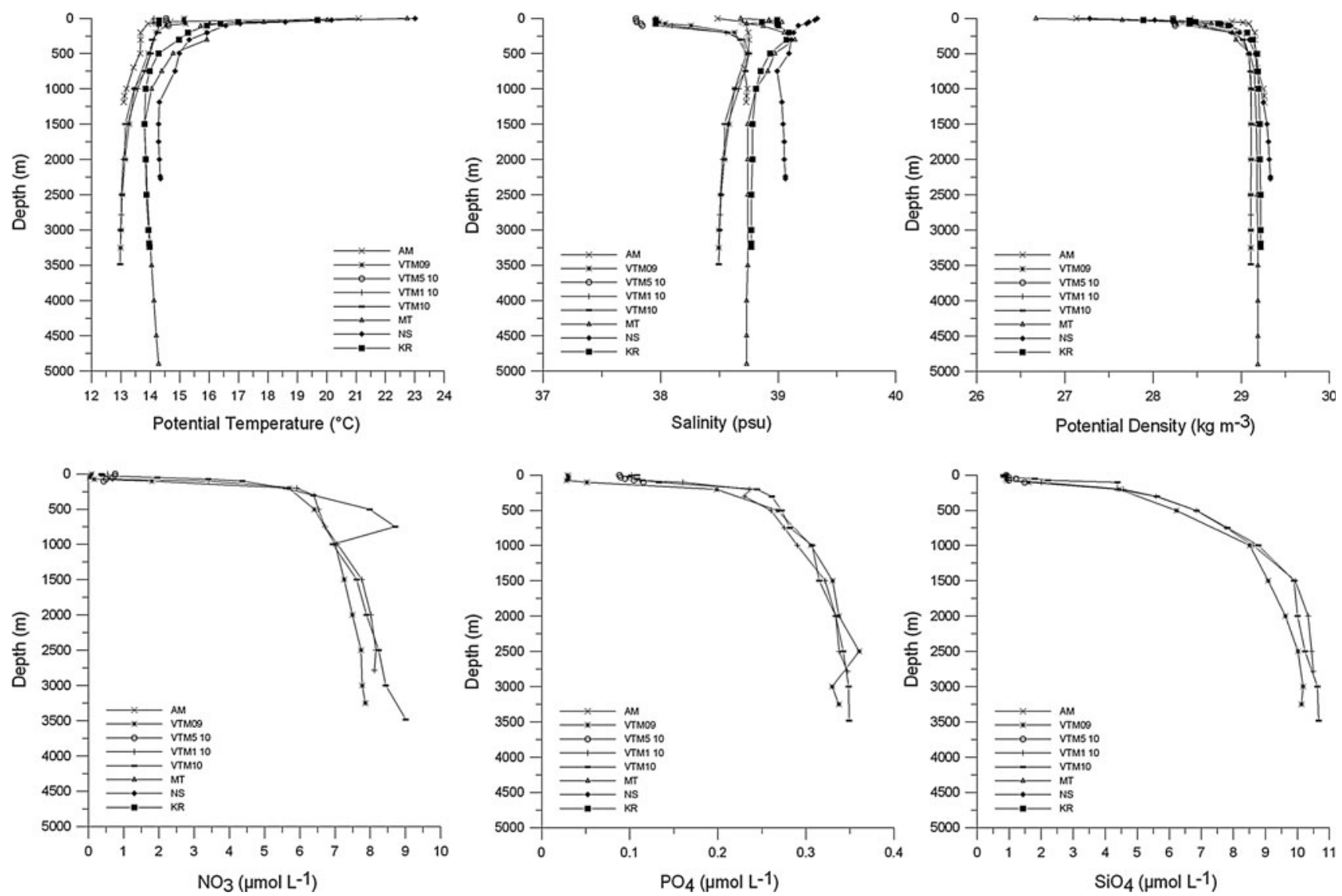

Fig. 2 Depth profiles of potential temperature $\left({ }^{\circ} \mathrm{C}\right)$, salinity $(\mathrm{psu})$, potential density $\left(\mathrm{kg} \mathrm{m}^{-3}\right)$ and nutrients $\left(\right.$ nitrate: $\mathrm{NO}_{3}$, phosphate: $\mathrm{PO}_{4}$ and silicate: $\mathrm{SiO}_{4}$ in $\mu \mathrm{mol} \mathrm{L}{ }^{-1}$ )

Table 2 Physical and chemical characteristics of the water samples as minima, maxima, median, mean values and standard deviations

\begin{tabular}{|c|c|c|c|c|c|c|c|c|c|c|c|}
\hline & $\begin{array}{l}\text { Potential } \\
\text { temperature } \\
{ }^{\circ} \mathrm{C}\end{array}$ & Salinity & $\begin{array}{l}\text { Potential } \\
\text { density } \\
\mathrm{kg} \mathrm{m}^{-3}\end{array}$ & $\begin{array}{l}\text { Dissolved } \\
\text { oxygen } \\
\text { CTD } \\
\mathrm{mg} \mathrm{L}^{-1}\end{array}$ & $\begin{array}{l}\text { Dissolved } \\
\text { oxygen } \\
\text { Winkler } \\
\mathrm{mg} \mathrm{L}^{-1}\end{array}$ & $\mu \mathrm{mol} \mathrm{L} \mathrm{L}^{-1}$ & $\mu \mathrm{mol} \mathrm{L} \mathrm{L}^{-1}$ & $\mu \mathrm{mol} \mathrm{L} \mathrm{L}^{-1}$ & DivinylChla & ChlaPico & ChlaN + M \\
\hline Min & 12.98 & 37.79 & 26.67 & 5.59 & 5.62 & 0.037 & 0.028 & 0.825 & 0.0041 & 0.0132 & 0.0045 \\
\hline Max & 23.01 & 39.33 & 29.33 & 8.14 & 7.95 & 9.011 & 0.381 & 10.660 & 0.0256 & 0.1348 & 0.1052 \\
\hline Median & 14.24 & 38.73 & 29.10 & 7.39 & 6.15 & 6.153 & 0.240 & 5.076 & 0.0152 & 0.0865 & 0.0332 \\
\hline Mean & 14.72 & 38.63 & 28.84 & 7.19 & 6.75 & 4.749 & 0.215 & 5.491 & 0.0133 & 0.0860 & 0.0389 \\
\hline SD & 1.93 & 0.39 & 0.49 & 0.82 & 0.90 & 3.296 & 0.113 & 3.897 & 0.0077 & 0.0359 & 0.0244 \\
\hline$n$ & 106 & 106 & 106 & 106 & 51 & 51 & 51 & 51 & 20 & 21 & 21 \\
\hline
\end{tabular}

Statistical analysis

Pearson's correlations are reported in Table 4. Prokaryotic cell size distribution is significantly correlated to depth, nutrient concentrations, HNA/LNA ratio and, at surface layer, with divinyl-chlorophyll. VOL results negatively correlated with PA, $\mathrm{PA}^{\mathrm{C}}$ and $\mathrm{PB}$. No significant correlation is observed between VOL and hydrology or oxygen concentration, suggesting that only biological and chemical factors affect the distribution of prokaryotic cell volume along the water column.

Cell size in the epipelagic layer is significantly different from the size measured in the mesopelagic layer $(P<0.05)$ and bathypelagic layers $(P<0.01)$ (ANOVA, data not shown). Significant variations in cell size occur with depth along the water column and are confirmed by the higher Shannon index found in the deep layers than at the surface (data not shown). 
Table 3 Prokaryotic cell volumes (VOL), carbon contents (CCC), abundances (PA), biomass (PB) by image analysis and prokaryotic cell abundances $\left(\mathrm{PA}^{\mathrm{C}}\right.$ ) and high nucleic acid to low nucleic acid ratios (HNA/LNA) by flow cytometry

\begin{tabular}{|c|c|c|c|c|c|c|}
\hline & $\begin{array}{l}\text { VOL } \\
\mu \mathrm{m}^{3}\end{array}$ & $\begin{array}{l}\mathrm{CCC} \\
\mathrm{fg} \mathrm{C} \text { cell }^{-1}\end{array}$ & $\begin{array}{l}\text { PA } \\
\text { Cell } \times 10^{5} \mathrm{ml}^{-1}\end{array}$ & $\begin{array}{l}\mathrm{PB} \\
\mu \mathrm{g} \mathrm{C} \mathrm{L}^{-1}\end{array}$ & $\begin{array}{l}\mathrm{PA}^{\mathrm{C}} \\
\text { Cell } \times 10^{5} \mathrm{ml}^{-1}\end{array}$ & HNA/LNA \\
\hline \multicolumn{7}{|l|}{ EPI } \\
\hline Min & 0.045 & 15 & 1.6 & 0.9 & 0.18 & 0.09 \\
\hline $\operatorname{Max}$ & 0.513 & 119 & 28.9 & 73.1 & 37.9 & 2.81 \\
\hline Median & 0.138 & 37 & 7.55 & 25.9 & 4.25 & 0.57 \\
\hline Mean & 0.176 & 46 & 9.75 & 26.2 & 6.25 & 0.64 \\
\hline SD & 0.116 & 26 & 6.2 & 15.7 & 7.08 & 0.43 \\
\hline$n$ & 46 & 46 & 46 & 46 & 46 & 46 \\
\hline \multicolumn{7}{|l|}{ MESO } \\
\hline Min & 0.049 & 16 & 0.75 & 1.4 & 0.18 & 0.26 \\
\hline Max & 0.466 & 110 & 8.2 & 35.0 & 7.73 & 3.70 \\
\hline Median & 0.227 & 59 & 3.08 & 12.1 & 1.34 & 1.20 \\
\hline Mean & 0.242 & 61 & 3.26 & 14.3 & 2.09 & 1.32 \\
\hline $\mathrm{SD}$ & 0.098 & 22 & 1.97 & 9.8 & 1.96 & 0.93 \\
\hline$n$ & 28 & 28 & 28 & 28 & 28 & 28 \\
\hline \multicolumn{7}{|l|}{ BATHY } \\
\hline Min & 0.069 & 20 & 0.4 & 1.6 & 0.19 & 0.34 \\
\hline Max & 0.566 & 129 & 3.08 & 17.3 & 2.72 & 3.33 \\
\hline Median & 0.217 & 56 & 0.93 & 4.5 & 0.51 & 1.53 \\
\hline Mean & 0.249 & 63 & 1.19 & 6.3 & 0.68 & 1.44 \\
\hline $\mathrm{SD}$ & 0.120 & 27 & 0.7 & 4.0 & 0.52 & 0.74 \\
\hline$n$ & 32 & 32 & 32 & 32 & 32 & 32 \\
\hline
\end{tabular}

Fig. 3 Vertical distribution of cell sizes (a) and cell abundances (b). Box plots range between the 25 th and the 75 th percentiles of a data set. The bold and the thin lines in the box represent the mean and the median, and the whiskers indicate the minimum and maximum values

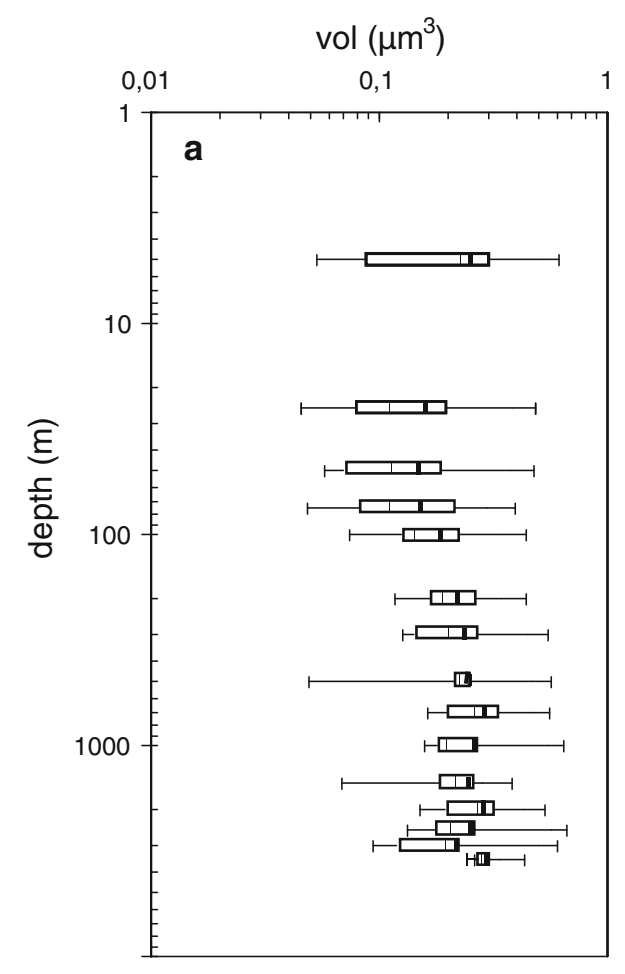


Table 4 Pearson's coefficient of correlations determined between the cell volumes and depth, cell abundance, biomass, abundance by cytometry, HNA/LNA ratio, nutrients, divinyl-chlorophyll $a$

\begin{tabular}{lrrl}
\hline Vol versus & \multicolumn{1}{l}{$r$} & \multicolumn{1}{l}{$n$} \\
\hline Depth & 0.249 & 106 & $<0.01$ \\
PA & -0.203 & 106 & $<0.05$ \\
PB & -0.307 & 106 & $<0.01$ \\
PA $^{C}$ & -0.203 & 106 & $<0.05$ \\
HNA/LNA & 0.394 & 106 & $<0.01$ \\
NO3 & 0.359 & 49 & $<0.01$ \\
PO4 & 0.355 & 49 & $<0.01$ \\
SiO4 & 0.350 & 49 & $<0.01$ \\
DivinylChl $a$ & 0.480 & 20 & $<0.05$ \\
\hline
\end{tabular}

$r=$ correlation coefficients, $n=$ number of data, $P=$ significance levels

Hierarchical cluster analysis (HCA) on the 13 depths between 5 and $2500 \mathrm{~m}$ on the basis of cell size is constructed with 78 complete data (Fig. 4); the two stations VTM5-10 and AM1 with incomplete depth data set are discarded. HCA identifies two main clusters grouping the superficial layers (similarity $66 \%$ )—mainly differentiated by the layer between 25 and $75 \mathrm{~m}(83 \%)$ and the layer between 100 and $200 \mathrm{~m}(77 \%)$, and the dark water column (58\%)-mainly differentiated in the intermediate layers (between 300 and $750 \mathrm{~m}, 72 \%$ ) and the deepest layers between 1,000 and 2,500 $\mathrm{m}(75 \%)$. The $5 \mathrm{~m}$ depth appears incongruent with other samples in the cluster. This finding suggests a non-homogeneous structure of the epipelagos probably due to the complex system of microbial processes occurring in the uppermost layer.
The PCA shows that the first axis explains up to $56 \%$ of the variability determined by the physical-chemical characteristics, mainly density, and $\mathrm{NO}_{3}$ and $\mathrm{PO}_{4}$ levels. The second component, representing $26 \%$ of the variability, is mainly constituted by biological parameters like morphometric (volume) and morphological (mainly coccal forms) ones.

\section{Cell morphology}

The class frequency of the dimensional sizes is reported in Fig. 5. Cell numbers are grouped for each area in which similar patterns are locally observed. On the whole, the most representative size class ranges between 0.12 and $0.19 \mu \mathrm{m}^{3}$, in which $25 \%$ of total cells are grouped. Secondary peaks are observed in the ranges $0.20-0.29$ and $0.04-0.079 \mu^{3}$ size, both accounting for $16 \%$ of the total. Thereafter, the smaller range $0.02-0.039 \mu \mathrm{m}^{3}$ represents $12 \%$ of the total.

The classes of cell length are reported in Fig. 6. The majority of the cells belong to the class of length $0.4-0.8 \mu \mathrm{m}$, accounting for $43 \%$ of the total cells, followed by the length classes of $0.8-1.2$ and $1.2-1.6 \mu \mathrm{m}$, which account for 22 and $13 \%$ of the total, respectively.

Among the different morphotypes, cocci are the most common morphotype and contribute on average for $41 \%$ to total prokaryotic cells; coccobacilli and rods account for 26 and $21 \%$, respectively; vibrios amount to $11 \%$ and spirillae are fairly negligible $(<1 \%)$. The contribution of each morphotype varies along the water column (Fig. 7a). Cocci and vibrios decrease from surface to the deeper layers, while rods show the opposite pattern. Coccobacilli
Fig. 4 Hierarchical cluster analysis (HCA) to test the similarity (group average linkage method) level of cell size versus depth

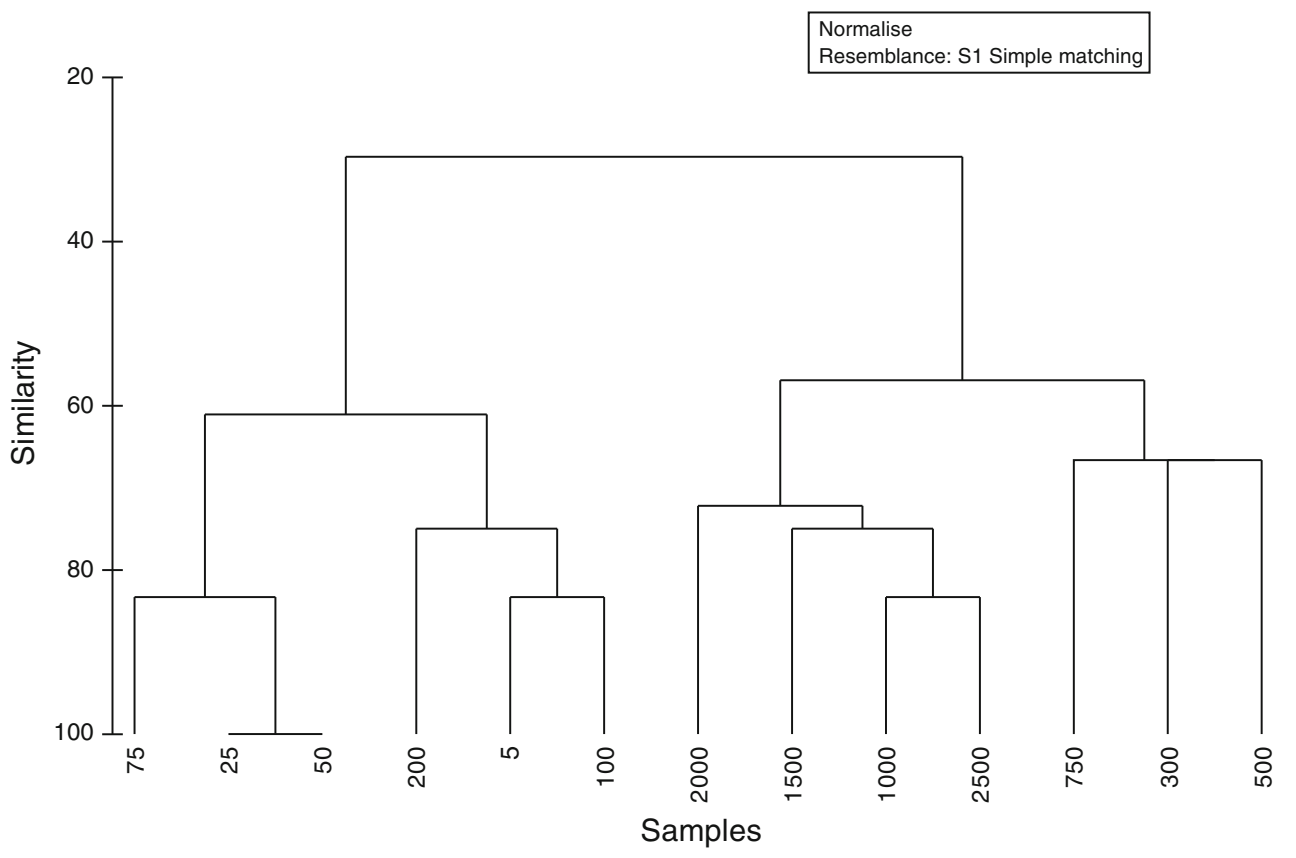




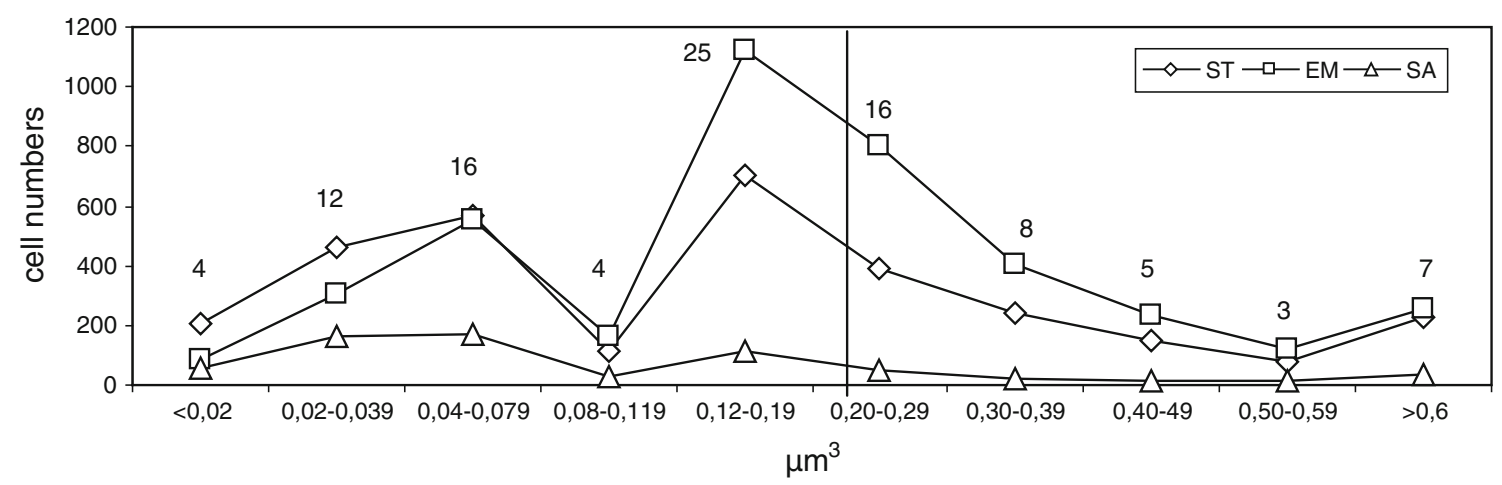

Fig. 5 Class frequency of the dimensional sizes obtained in the three studied areas (ST, EM and SA). The vertical bar represented the mean value of the cell volumes, and the numbers represent the percentage of the size class on the total cell numbers

Fig. 6 Size classes of cell length obtained in the three studied areas (ST, EM and SA). The vertical bar represented the mean value of the cell lengths, and the numbers represent the percentage of the length class on the total cell numbers

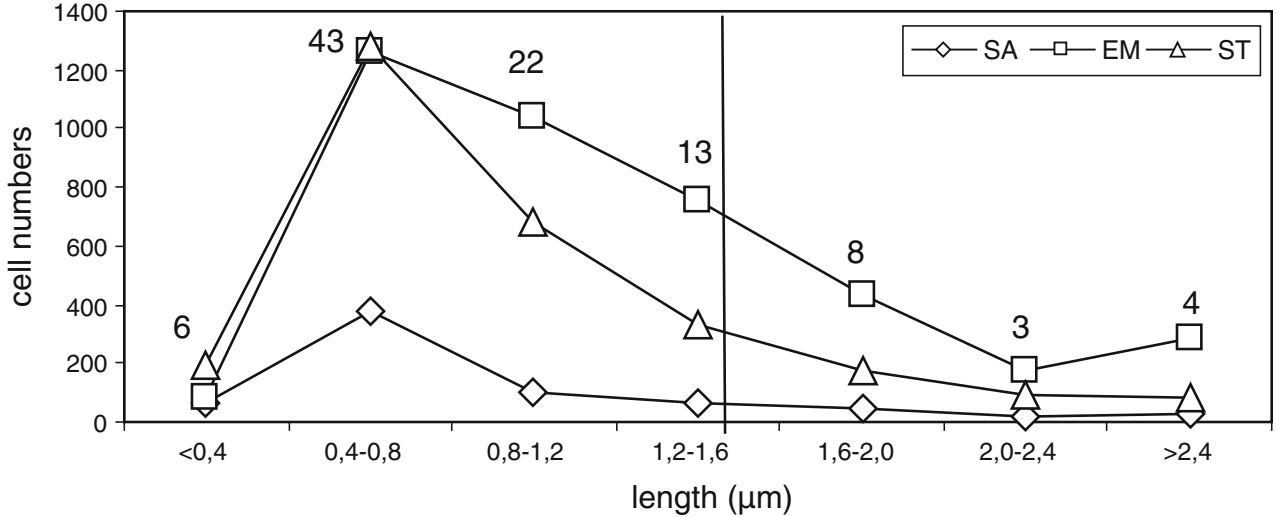

increase in the mesopelagic layer. In general, the size of the different morphotypes shows similar patterns with depth with increased volumes toward the waters relatively deep to the surface layer (Fig. 7b). Vibrios and rods show the highest volumes in the mesopelagic layers. Small to medium-sized rods-arranged in chain or in long linear filaments with visible or unvisible septae-and curved rods are detected in the meso- and bathypelagic layers in the EM area.

Biomass, calculated on the above morphotypes-taking into account abundance and size-is mainly composed by coccobacilli (37\% of total biomass) and rods (31\%). Cocci account for $20 \%$, vibrios for $12 \%$ and spirillae for $<1 \%$ of the total biomass.

\section{Discussion}

Prokaryotic cell volume distribution along the water column

The calculation of cell volume provides a taxonomic approach for analyzing the ecosystems structure allowing us to better quantify biomass as well as cell heterogeneity in mixed assemblages (Quinones et al. 2003). Moreover, it has been hypothesized that changes in size or shapes or morphology of unicellular bodies, including prokaryotic cells, can be a sensitive indicator of trophic and climatic changes in aquatic ecosystems (Pernthaler and Amann 2005).

Our results show that large cells, with volumes ranging between 0.1 and $0.3 \mu \mathrm{m}^{3}$, dominate the total prokaryotic assemblage. The ranges of cell size are generally higher than those previously referred by La Ferla et al. (2010) in different MED areas but similar to those measured by Azzaro et al. (2011) in the South Adriatic Sea and by Misic et al. (2008) in the Tyrrhenian Sea, being the latest estimated by acridine orange direct counts. Cellular sizes measured in our study are also higher than those reported for oceanic areas (Lee and Fuhrman 1987; Pedrós-Alió et al. 1999) even though few data are available since most of the studies dealt with cell size variability measured in laboratory or mesocosm experiments (Heldal et al. 1994). In the Baltic Sea, Blackburn et al. (1998) and Heinanen (1991) determined smaller cell volumes within ranges of $0.023-0.232$ and $0.021-0.072 \mu \mathrm{m}^{3}$, respectively. Moreover, Heinanen (1991) reported higher cell size during the vernal phytoplankton bloom than in summer, mainly in 
Fig. 7 Cell numbers (a) and sizes (b) of the different morphotypes in each depth layers (epi-, meso- and bathypelagic)
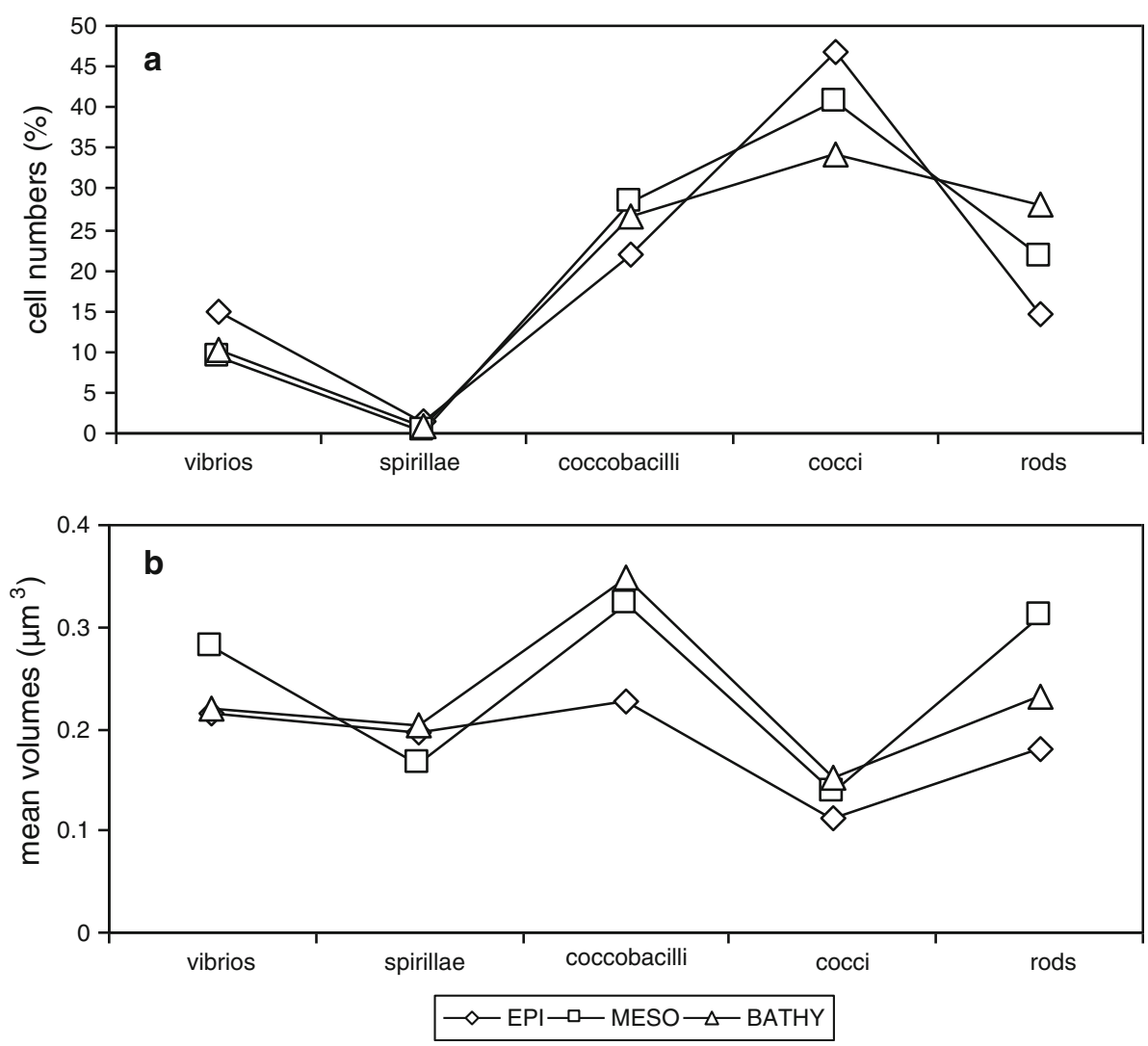

relation with river discharge. Conversely in our study, seasonal differences in cell size are not detected, probably because a low coastal effect on the studied ecosystems. However, increases in cell size are highlighted over the 3 years.

The synoptic analysis of cell volume distribution shows different microbial behavior along the water column. The prokaryote cell size increasing with depth is confirmed by statistics that assert the significant differences between the epipelagic and the two deeper layers (ANOVA, H' index). HCA also shows how cell sizes are grouped in the different depth layers, roughly representing the main MED water masses. Indeed, the surface layer-accounting for the water mass between the surface and $200 \mathrm{~m}$ depth-can be approximately associated with the Atlantic Surface Water (ASW), the layer between 300 and $750 \mathrm{~m}$ depth with the intermediate water (LIW) and the layer below 1,000 m depth with the MED deep waters (Robinson et al. 2001). Since the conversion factors from prokaryotic cell counting to biomass partially depend on the VOL estimates, our results strongly suggest that different cell carbon content must be applied within the different water masses along the water column for calculating the prokaryotic biomass by cell counting (Tanaka 2009). As a matter of fact, applying the most currently adopted carbon conversion factor of $20 \mathrm{fg} \mathrm{cell}^{-1}$ to our cell counts, the resulting mean biomass would be underestimated by two or three times in the photic and aphotic layers, respectively. In our study, the averaged locally derived cell carbon contents (46, 61, and $63 \mathrm{fg} \mathrm{C} \mathrm{cell}^{-1}$ in the epi-, meso- and bathypelagic layers, respectively) are significantly higher than previous data obtained in other oceanic areas or in the MED (Table 5). In the North Sea, the amount of $\mathrm{C}$ per bacterial cell varied between 15 and $80 \mathrm{fg} \mathrm{C}^{-1}$ cell $^{-1}$ depending on particle aggregation, and thus on seasonal inputs (Becquevort et al. 1998). A fortiori, our results confirm the uncertainty of the ecological implication deriving from the use of a constant $\mathrm{CCC}$ for biomass quantification and point out the degree of variability in cell volumes with time and space.

Morphotypes distribution along the water column

Each morphotype shows variability in size and abundance along the water column. Our results confirm the existence of different populations along the water column as already assessed by more specific biomolecular techniques in samples of the Tyrrhenian Sea (Tamburini et al. 2009) and North Atlantic (Reinthaler et al. 2006). Coccal forms and coccobacilli are the main contributors of the biomass. The shift of morphotype along the water column is clear, with small coccal form prevailing at surface while great-elongated forms dominate at depth. In the South China Sea, $\mathrm{Hu}$ 
Table 5 A synthesis of CCC obtained in Mediterranean and Oceanic seawater samples

\begin{tabular}{lll}
\hline References & CCC & Areas \\
\hline Lee and Fuhrman (1987) & $20 \mathrm{fg} \mathrm{C} \mathrm{cell}^{-1}$ & NW-Atlantic \\
Ducklow and Carlson (1992) & $20 \mathrm{fg} \mathrm{C} \mathrm{cell}^{-1}$ & Oceans \\
Christian and Karl (1994) & $10-15 \mathrm{fg} \mathrm{C} \mathrm{cell}^{-1}$ & Pacific (Aloha Station) \\
Caron et al. (1995) & $10-15 \mathrm{fg} \mathrm{C} \mathrm{cell}^{-1}$ & Sargasso Sea \\
Fukuda et al. (1998) & $12-30 \mathrm{fg} \mathrm{C} \mathrm{cell}^{-1}$ & Coastal Southern and \\
& & Pacific Oceans \\
Gundersen et al. (2002) & $4-9 \mathrm{fg} \mathrm{C} \mathrm{cell}^{-1}$ & N-Atlantic \\
La Ferla et al. (2004) & $19 \mathrm{fg} \mathrm{C} \mathrm{cell}^{-1}$ & Ionian Sea \\
La Ferla and Leonardi (2005) & $6-42 \mathrm{fg} \mathrm{C} \mathrm{cell}^{-1}$ & North Adriatic \\
La Ferla et al. (2010) & $14-22 \mathrm{fg} \mathrm{C} \mathrm{cell}^{-1}$ & South Tyrrhenian \\
Williams and Carlucci (1976) & $10 \mathrm{fg} \mathrm{C} \mathrm{cell}^{-1}$ & North-Central Pacific Ocean \\
Becquevort et al. (1998) & $15-80 \mathrm{fg} \mathrm{C} \mathrm{cell}^{-1}$ & North Sea \\
Børsheim et al. (1990) & $300{\mathrm{fg} \mathrm{C} \mu \mathrm{m}^{-3}}^{-3}$ & Roskilde Fjord (Norway) \\
Bjornsen and Kuparinen (1991) & $390{\mathrm{fg} \mathrm{C} \mu \mathrm{m}^{-3}}$ & Scotia Sea \\
\hline
\end{tabular}

et al. (2011) highlighted a depth partitioning in the prokaryotic community structure and clones libraries of crenarchaeal genes showed two depth-dependent clusters: a "shallow" and a "deep" cluster in the epipelagic and in the meso- and bathypelagic layers, respectively. Morris et al. (2002), in the northwestern Sargasso Sea, reported a numerical shift of small-sized SAR11 (curved rods of less than $1 \mu \mathrm{m}$ ) to larger-sized Archaea along the water column. Moreover, these authors affirmed that in many of the studied environments, SAR1 1 is the most dominant organism, accounting for an average of $35 \%$ of surface water and $18 \%$ of mesopelagic cell counts in both coastal and open ocean systems. In our case, we cannot exclude the occurrence of this clade, these cells being difficult to properly distinguish in image analysis because of their small size, close to the limit of resolution of light microscopy.

A further approach developed by Posch et al. (2009), using a combination of CARD-FISH and image analysis to discriminate between different morphotypes and their taxonomic affiliation, has shown how this combination is useful to provide the simultaneous analysis of both morphotypes and phylogenetic lineages. Formerly, combination between confocal laser scanning microscopy, allowing determinations of bacterial numbers, volumes and dividing cells by and image analysis, have been successfully applied by Bloem et al. (1995).

Comparison of cell volumes and environmental parameters

Hydrology does not affect cell size variability, as revealed by the lack of significant correlation between cell size and temperature or salinity. This result agrees with the findings of Li and Dickie (1996) asserting that, at large scale, temperature exerts only a direct significant influence on the cell abundance below $14^{\circ} \mathrm{C}$, while above $14^{\circ} \mathrm{C}$ temperature does not affect cell abundance. The high temperature of MED seawater (always $\sim 13^{\circ} \mathrm{C}$ below the seasonal thermocline down to the bottom and during winter mixing period) relatively to the oceanic ones does not limit the deep microbial growth (Tanaka 2009).

The hydrostatic pressure alone may not be a constraining factor for cell size. Indeed, many prokaryotes are piezophiles and physiologically well adapted to high pressure. Studies in laboratory show that pressure affects cell division but not cell growth (Barlett 2002).

Response of bacteria to pressure seems to be strain dependent as revealed by Grossart and Gust (2009), which showed that selected strains respond individually to pressure exposition with strong physiological response during sinking. A study by Oger and Jebbar (2010) revealed adaptive strategies to high hydrostatic pressures in prokaryotes to maintain appropriate cell turgor and fluid balance.

Turbulence of water column also might affect the distribution of prokaryotes, for instance influencing the grazing pressure that appears to be lower under turbulent conditions (Peters et al. 2002).

Other environmental variables, as nutrients, are responsible for varying bacterial cell size. A coupling between environmental trophic level and composition or size variability of bacterioplankton populations has been observed by Ducklow and Carlson (1992). Vrede et al. (2002) showed that morphology, biomass, size, abundance and C content changed according to nutrient and substrate limitations on growing cultured bacteria. Interestingly, Øvreås et al. (2003) from a mesocosm study showed that a new population of large rod-shaped bacteria is able to develop following the addition of glucose together with inorganic nutrients. These authors hypothesized a shift from a 
bacterial community dominated by species with high ability to compete for organic carbon source to a community dominated by species with a high ability to compete for mineral nutrients. Cells with the capacity to store glycogen are able to increase their size without a parallel increase in the cellular requirement for the limiting nutrient.

From our results, the hypothesis that fluctuations in nutrient availability influence cell volume is confirmed as revealed by the significant correlation found between cell volume and nutrient concentrations. This can be due to a shift of population according to their efficiency to compete for the available resources throughout the water column. These features suggest a certain degree of bottom-up control (Eiler et al. 2011). Indeed, in the surface layer, cell size covaries with divinyl-chlorophyll $a$ concentration, probably in relation with the fact that this pigment biomarker of Prochloroccus is much higher in the deepchlorophyll maximum, corresponding to the biomass and nutrient-rich layer (Zaccone et al. 2004).

The inverse correlation between the cell number and size is intriguing. Epipelagic layers are characterized by abundant and small cells, among which coccal forms show the highest relative frequency, while in the deep layers, cell concentration is lower and characterized by greater volumes of rods, coccobacilli and vibrios, and higher presence of rods. Racy et al. (2005) suggest that in high productive conditions (chlorophyll $a$ rich and thus young and labile organic matter availability) the numerical increase of spheroidal cells (cocci and coccobacilli) is favored, due to a more efficient reproductive strategy. This result fits with our higher presence of coccal forms in the surface layer where phytoplankton grows. On the other hand, the hypothesis that abundant and dwarf forms also might use the strategy by getting smaller to increase the surface, especially in oligotrophic environments, cannot be excluded.

Conversely, in the deep layers where phytoplankton is absent and richer in more recalcitrant substrata, cell abundance is lower and the low resources are probably used by cells for optimizing growth, instead of division, which is more expensive in terms of energetic cost (Racy 2004). This hypothesis might be confirmed by the increase in the leucine/thymidine uptake ratios in growing bacterial cells in oceanic environments (Kirchman et al. 1986). Even in reducing cell division due to stressful conditions, cell growth continues. Thanks to this mechanism, the organism is able to increase its surface area, providing itself with greater contact with the medium and so enhancing its capacity to capture the scarce resources from the surroundings. Our study corroborates this hypothesis since the inverse correlation between cell count and size, a sort of microbial phenomenon of "gigantism".
To our knowledge, studies comparing prokaryotic cell volume and carbon pools are few in marine ecosystems, as in the MED sea where relationships between DOC and POC distributions and microbial community are scarce ( $\mathrm{La}$ Ferla et al. 2006; Sempéré et al. 2000; Zaccone et al. 2002). Santinelli et al. (2010) hypothesized a different functioning of the microbial loop, mainly linked to the semi-labile fraction of DOC in the deep MED layers. The higher DOC concentration found in the deepest layer relatively to the intermediate layers in the MED may be linked to different cell size dominance in these layers, in relation with different behavior in the metabolic functioning of prokaryotic populations along the water column. Studies on DOC availability to prokaryotic enzymatic activity highlighted different behavior in different areas of MED. The increase in the cell-specific activities with depth was mainly found in the more oligotrophic Eastern basin as well as an active microbial community metabolizing proteinaceous substrates was found in the bathypelagic layer of the Tyrrhenian Sea (Zaccone et al. 2012).

Cell size variations affect the prey-predator relationship. Indeed, size is a relevant factor influencing susceptibility to protistan grazing, with a refuge at the lower and upper ends of the prokaryotic cell size range (Jürgens and Güde 1994). Hence, a relative grazing resistance can be assumed for the so-called ultramicrobacteria and for complex forms such as the filaments and aggregates. Protista primarily feed on particular morphotypes in natural mixed assemblages (Peters et al. 2002), and Arístegui et al. (2009) suggested that heterotrophic nanoflagellates might control prokaryotic abundance in the meso-bathypelagic systems in the same way as in epipelagic water.

The dominant cell volume found in our study ranged between 0.1 and $0.3 \mu \mathrm{m}^{3}$, and cell volume distribution appears unclear when compared with the Pernthaler's diagram on the effect of predation on the microbial community structure (Pernthaler 2005). Indeed, most of the cells are distributed close to the mean size, and the absence of cells volume ranging between 0.08 and $0.119 \mu \mathrm{m}^{3}$ suggests a selective predation over these cell dimensions. In different areas as a subarctic estuary, the microbial cell volumes are controlled by predators in summer and by the resources (inorganic nutrients, carbon) available in other periods (Heinanen 1992). Since the impact of bacterial cell volume is less relevant than cell length for feeding efficiency of the heterotrophic nanoflagellate (Matz et al. 2002), the length frequency classes are determined. In our samples, the most frequent length is ranged between 0.4 and $0.8 \mu \mathrm{m}$, and the prokaryotic population is mainly distributed far from the mean length value. According to Pernthaler and Amann (2005) in pelagic habitats, heterotrophic flagellates preferably ingest microbial cells within a length range of 1-3 $\mu \mathrm{m}$, and by consequence smaller cells 
take advantage of the low grazing rate. Unfortunately, we do not have any data on predation in this study, but cell length frequencies suggest a weak top-down control on the prokaryotic population longer than $1.2 \mu \mathrm{m}$. Recent results in the MED from dilution experiments suggested a high effect of potential predation of heterotrophic nanoflagellates on prokaryotic abundance (on average $49.5 \%$ ) at $1,500 \mathrm{~m}$ depth (Fonda Umani et al. 2010). However, different behaviors of the heterotrophic nanoflagellate grazing pressure on prokaryotes growth rates are observed relatively to the different biogeographic regions, for instance being higher in the western than in the eastern MED basin. In the latter, the prokaryotic growth is higher than mortality. The opposite is observed in the western basin, as in the Tyrrhenian Sea, where heterotrophic nanoflagellates are able to control prey abundance. However, in our samples, noticeable differences between the size and length frequencies are not detected over the three sampled areas.

Finally, a relevant role of high viral abundance occurring in the meso- and bathypelagic waters of MED on cell size distribution could not be excluded mainly in the Eastern basin (Magagnini et al. 2007).

These previous results on nanoflagellates and viruses corroborate our results about the weak top-down control hypothesized in our study.

At a methodological point of view, flow cytometry underestimates cell counts relatively to image analysis probably due to the weak fluorescence signal by smaller cells as already observed by Heldal et al. (1994). The relative contribution of HNA cells to total abundance strongly fluctuates, and the depth-dependent pattern agrees with the increasing cell sizes with depth. Indeed, the shift in dominance from low-DNA to high-DNA cells below the epipelagic layer is probably linked to cell size increase with depth.

\section{Conclusions}

The novelty of our study consists in considering cell size as a functional parameter in marine prokaryotic studies. Our results show that a usually-not-considered form of carbon sequestration through the prokaryotic cells exists in the deep MED. Such sequestration can be greater than normally thought, due to consistent increase in cell size in the dark water column. Different factors might affect cell size and morphology distribution, as a probable response to environmental condition variations (both biotic and abiotic) along the water column. Bottom-up and top-down controls on prokaryotic cell size can be hypothesized. Although assessing the prokaryotic size and morphology by microscopy is slow and labor-intensive, our results lead to the thesis that VOL calculation must be locally applied for CCC determination, at least within the different water masses, in order to more correctly calculate biomass concentration.

Acknowledgments The authors thank the colleagues at CNR IAMC: F Soraci, A Cosenza, V La Cono for their valuable contribution, as well as G Caruso for her support in statistic. The research was supported by funds of VECTOR-CARPEL project (MIUR-Ministero Italiano dell'Università e Ricerca), STM-Short Term Mobility 2009 (AMMCNT - CNR n. 0051228), RSTL-Ricerca Spontenea a Tema Libero of CNR (cod. 483) and MAMBA project (EU.FP6). AS Cabral was funded by a CNPq Post-doc scholarship, and R Paranhos was funded by CNPq, CAPES and FAPERJ.

\section{References}

Amalfitano S, Fazi S, Puddu A (2009) Flow cytometric analysis of benthic prokaryotes attached to sediment particles. J Microbiol Meth 79:246-249

Andrade L, Gonzalez AM, Araujo FV, Paranhos R (2003) Flow cytometry assessment of bacterioplankton in tropical marine environments. J Microbiol Meth 19:89-94

Arístegui J, Gasol GM, Duarte CM, Herndl GJ (2009) Microbial oceanography of the dark ocean's pelagic realm. Limnol Oceanogr 54:1501-1529

Azzaro M, La Ferla R, Maimone G, Monticelli LS, Zaccone R, Civitarese G (2011) Prokaryotic dynamics and heterotrophic metabolism in a deep-convection site of Eastern Mediterranean Sea (the Southern Adriatic Pit). Cont Shelf Res. doi:10.1016/ j.csr.2011.07.011

Barlett DH (2002) Pressure effects on in vivo microbial processes. Biochimica Biophys Acta 1595:367-381

Becquevort S, Rousseau V, Lancelot C (1998) Major and comparable roles for free-living and attached bacteria in the degradation of Phaeocystis-derived organic matter in Belgian coastal waters of the North Sea. Aquat Microb Ecol 14:39-48

Bjornsen PK, Kuparinen J (1991) Determination of bacterio-plankton biomass, net production and growth efficiency in the southern ocean. Mar Ecol Prog Ser 71:185-194

Blackburn N, Hagström Å, Wikner J, Cuadros-Hansson R, Bjørnsen PK (1998) Rapid determination of bacterial abundance, biovolume, morphology, and growth by neural network-based image analysis. Appl Environ Microbiol 64:32-46

Bloem J, Veninga M, Shepard J (1995) Fully automatic determination of soil bacterium numbers, cell volumes, and frequencies of dividing cells by confocal laser scanning microscopy and image analysis. Appl Environ Microbiol 61:926-936

Bölter M, Möller R, Dzomla W (1993) Determination of bacterial biovolume with epifluorescence microscopy: comparison of size distributions from image analysis and size classifications. Micron 24:31-40

Bölter M, Bloem J, Meiners K, Möller R (2002) Enumeration and biovolume determination of microbial cells - a methodological review and recommendations for applications in ecological research. Biol Fertil Soils 36:249-259

Bölter M, Bloem J, Meiners K, Möller R (2006) Enumeration and biovolume determination of microbial cells. In: Bloem J, Hopkins DW, Benedetti M (eds) Microbiological methods for assessing soil quality. CABI Publishing, UK, pp 93-113

Bouvier T, del Giorgio PA, Gasol JM (2007) A comparative study of the cytometric characteristics of high and low nucleic-acid bacterioplankton cells from different aquatic ecosystems. Environ Microbiol 9:2050-2066 
Button DK, Robertson BR (2001) Determination of DNA content of aquatic bacteria by flow cytometry. Appl Environ Microbiol 67:1636-1645

Caron DA, Dam HG, Kremer P, Lessard EJ, Madink LP, Malone TC, Napp JM, Peele ER, Roman MR, Youngbluth MJ (1995) The contribution of microorganisms to particulate carbon and nitrogen in surface waters of the Sargasso Sea near Bermuda. Deep-Sea Res 42:943-972

Carpenter JH (1965) The accuracy of the Winkler method for the dissolved oxygen analysis. Limnol Oceanogr 10:135-140

Caruso G, Azzaro M, Maimone G, Caruso R, Zappalà G (2010) Abundance and distribution of actively respiring bacteria in a coastal-offshore transect of the Tyrrhenian Sea (April 2007). 39th CIESM, Venice 10-14 May 2010, vol 39, p 342

Casotti R, Landolfi A, Brunet C, D’Ortenzio F, Mangoni O, Boldrin A, Ribera d'Alcalà M, Denis M (2003) Composition and dynamics of the phytoplankton of the Ionan Sea (Eastern Mediterranean). J Geophys Res 108(C9):8116

Christian JR, Karl DM (1994) Microbial community structure at the US-JGOFS Station ALOHA: inverse methods for estimating biochemical indicator ratios. J Geophys Res 99:14269-14276

Clarke KR, Gorley RN (2006) PRIMER v6: user manual/tutorial. PRIMER-E, Plymouth

Danovaro R, Dell'Anno A, Corinaldesi C, Magagnini M, Noble R, Tamburini C, Weinbauer M (2008) Major viral impact on the functioning of benthic deep-sea ecosystems. Nature 454:1084-1088

Dimier C, Corato F, Tramontano F, Brunet C (2007) Photoprotection and xanthophyll cycle activity in three diatoms. J Phycol 43:937947

Ducklow HW, Carlson CA (1992) Oceanic bacterial production. In: Marshall KC (ed) Advances in microbial ecology. Plenum Press, New York, pp 113-181

Eiler A, Hayakawa DH, Rappé MS (2011) Non random assembly of bacterioplankton communities in the subtropical North Pacific Ocean. Front Microbio 2:140. doi:10.3389/fmicb.2011.00140

Fazi S, Amalfitano S, Piccini C, Zoppini A, Puddu A, Pernthaler J (2008) Colonization of overlaying water by bacteria from dry river sediments. Environ Microbiol 10:2760-2772

Felip M, Andreatta S, Sommaruga R, Staskràbovà V, Catalan J (2007) Suitability of flow cytometry for estimating bacterial biovolume in natural plankton samples: comparison with microscopy data. Appl Environ Microbiol 73:4508-4514

Fonda Umani S, Malisana E, Focaracci F, Magagnini M, Corinaldesi C, Danovaro R (2010) Disentangling the effect of viruses and nanoflagellates on prokaryotes in bathypelagic waters of the Mediterranean Sea. Mar Ecol Prog Ser 418:73-85

Fukuda R, Ogawa H, Nagata T, Koike I (1998) Direct determination of carbon and nitrogen contents of natural bacterial assemblages in marine environments. Appl Environ Microbiol 64:3352-3358

Gasol JM, del Giorgio PA (2000) Using flow cytometry for counting natural planktonic bacteria and understanding the structure of planktonic bacterial communities. Sci Mar 64:197-224

Gasol JM, Zweifel UL, Peters F, Fuhrman JA, Hagström ^̊ (1999) Significance of size and nucleic acid content heterogeneity as measured by flow cytometry in natural planktonic bacteria. Appl Environ Microbiol 65:4475-4483

Grasshoff K (1976) Methods of seawater analysis, New York

Grossart HP, Gust G (2009) Hydrostatic pressure affects physiology and community structure of marine bacteria during settling to 4000 m: an experimental approach. Mar Ecol Prog Ser 390:97104

Gundersen K, Heldal M, Norland S, Purdie DA, Knap AH (2002) Elemental C, N, P cell content of individual bacteria collected at the Bermuda Atlantic Time-series Study (BATS) site. Limnol Oceanogr 47:1525-1530
Heinanen A (1991) Bacterial numbers, biomass and productivity in the Baltic Sea: a cruise study. Mar Ecol Prog Ser 70:283-290

Heinanen A (1992) Bacterioplankton in a subarctic estuary: the Gulf of Bothnia (Baltic Sea). Mar Ecol Prog Ser 86:123-131

Heldal M, Norland S, Bratbak G, Riemann B (1994) Determination of bacterial cell number and cell volume by means of flow cytometry, transmission electron microscopy, and epifluorescence microscopy. J Microbiol Meth 20:255-263

Hu A, Jiao N, Zhang CL (2011) Community structure and function of planktonic Crenarchaeota: changes with depth in the South China Sea. Microb Ecol. doi:10.1007/s00248-011-9866-z

Jochem FJ (2001) Morphology and DNA content of bacterioplankton in the northern Gulf of Mexico: analysis by epifluorescence microscopy and flow cytometry. Aquat Microb Ecol 25:179-194

Jolliffe I (2005) Principal component analysis. Encyclopedia of Statistics in Behavioral Science. doi:10.1002/0470013192. bsa501

Jürgens K, Güde H (1994) The potential importance of grazingresistant bacteria in planktonic systems. Mar Ecol Prog Ser 112:169-188

Kalcheva H, Beshkova M, Pehlivanov L, Kalcev R (2008) Bacterioplankton dynamics and the influence of environmental factors on it in the Srebarna Lake. The third international scientific conference BALWOIS, Ohrid, Republic of Macedonia-27, 31 May 2008

Kirchman DL, Newell SY, Hodson RE (1986) Incorporation versus biosynthesis of leucine: implications for measuring rates of protein synthesis and biomass production by bacteria in marine systems. Mar Ecol Prog Ser 32:47-59

Krambeck C, Krambeck HJ, Overbeck J (1981) Microcomputer assisted biomass determination of plankton bacteria on scanning electron micrographs. Appl Environ Microbiol 42:142-149

La Ferla R, Leonardi M (2005) Ecological implications of biomass and morphotype variations of bacterioplankton: an example in a coastal zone of the Northern Adriatic Sea (Mediterranean). Mar Ecol 26:82-88

La Ferla R, Lo Giudice A, Maimone G (2004) Morphology and LPS content for the estimation of marine bacterioplankton biomass in the lonian Sea. Sci Mar 68:23-31

La Ferla R, Azzaro M, Maimone G (2006) Microbial respiration and trophic regimes in the northern Adriatic Sea (Mediterranean Sea). Estuar Coast Shelf Sci 69:196-204

La Ferla R, Azzaro M, Budillon G, Caroppo C, Decembrini F, Maimone G (2010) Distribution of the prokaryotic biomass and community respiration in the main water masses of the Southern Tyrrhenian Sea (June and December 2005). Adv Oceanogr Limnol 2:235-257

Lebaron P, Servais P, Baudoux AC, Bourrain M, Courties C, Parthuisot N (2002) Variations of bacterial-specific activity with cell size and nucleic acid content assessed by flow cytometry. Aquat Microb Ecol 28:131-140

Lee S, Fuhrman A (1987) Relationship between biovolume and biomass of naturally derived bacterioplankton. Appl Environ Microbiol 53:1298-1303

Li WKW, Dickie PM (1996) Distribution and abundance of bacteria in the ocean. Fisheries and Oceans Canada. http://www.mar. dfo-mpo.gc.ca/science/review/1996/Li/Li_e.html

Loferer-Krößbacher M, Klima J, Psenner R (1998) Determination of bacterial cell dry mass by transmission electron microscopy and densitometric image analysis. Appl Environ Microbiol 64:688694

Magagnini M, Corinaldesi C, Monticelli LS, De Domenico E, Danovaro R (2007) Viral abundance and distribution in mesopelagic and bathypelagic waters of the Mediterranean Sea. Deep Sea Res I 54:1209-1220 
Mahadevaswamy M, Yamakanamardi SM, Harsha TS (2008) Bacterial (free-living and particle bound) cell-size in the surface waters of river Cauvery and its upstream tributaries in Karnataka State, India. Appl Ecol Environ Res 6:29-47

Massana R, Gasol JP, Bjørnsen PK, Blackburn N, Hanström A, Hietanen S, Hygum BH, Kuparinen J, Pedrós-Alió C (1997) Measurement of bacterial size via image analysis of epifluorescence preparations: description of an inexpensive system and solutions to some of the most common problems. Sci Mar 61: 397-407

Matz C, Boenigk J, Arndt H, Jürgens K (2002) Role of bacterial phenotypic traits in selective feeding of the heterotrophic nanoflagellate Spumella sp. Aquat Microb Ecol 27:137-148

Misic C, Castellano M, Ruggieri N, Covazzi Harriague A (2008) Variations in ectoenzymatic hydrolitic activity in an oligotrophic environment (Southern Tyrrhenian Sea, W Mediterranean). J Mar Sys 73:123-137

Moran XAG, Bode A, Suárez SA, Nogueira E (2007) Assessing the relevance of nucleic acid content as an indicator of marine bacterial activity. Aquat Microb Ecol 46:141-152

Morris RM, Rappe MS, Connon SA, Vergin KL, Siebold WA, Carlson CA, Giovannoni SJ (2002) SAR11 clade dominates ocean surface bacterioplankton communities. Nature 420:806810

Nagata T, Tamburini C, Aristegui J, Baltar F, Bochdansky AB, Fonda-Umani S, Fukuda H, Gogou A, Hansell DA, Hansmen RL, Herndl GJ, Panagiotopoulos C, Reinthaler T, Sohrin R, Verdugo P, Yamada N, Yamashita Y, Yokokawa T, Barlett DH (2010) Emerging concepts on microbial processes in the bathypelagic ocean-ecology, biogeochemistry, and genomics. Deep-Sea Res II 57:1519-1536

Oger PM, Jebbar M (2010) The many ways of coping with pressure. Res Microbiol 161:799-809

Øvreås L, Bourne D, Sandaa RA, Casamayor EO, Benlloch S, Goddard V, Smerdon G, Heldal M, Thingstad TF (2003) Response of bacterial and viral communities to nutrient manipulations in seawater mesocosms. Aquat Microb Ecol 31:109-121

Pedrós-Alió C, Calderón-Paz JI, Guixa-Boixereu N, Estrada M, Gasol JM (1999) Bacterioplankton and phytoplankton biomass and production during summer stratification in the northwestern Mediterranean Sea. Deep Sea Res I 46:985-1019

Pernthaler J (2005) Predation on prokaryotes in the water column and its ecological implications. Nat Rev Microbiol, AOP. doi: 10.1038/nrmicro1180

Pernthaler J, Amann R (2005) Fate of heterotrophic microbes in pelagic habitats: focus on populations. Microbiol Mol Biol Rev 69:440-461

Pernthaler J, Šimek K, Sattler B, Schwarzenbacher A, Bobkova J, Psenner R (1996) Short-term changes of protozoan control on autotrophic picoplankton in an oligo-meso-trophic lake. J Plankton Res 18:443-462

Peters F, Marrasé C, Havskum H, Rassoulzadegan F, Dolan J, Alcaraz M, Gasol JM (2002) Turbulence and the microbial food web: effects on bacterial losses to predation and on community structure. J Plankton Res 24:321-331

Porter KG, Feig YS (1980) The use of DAPI for identifying and counting aquatic microflora. Limnol Oceanogr 25:943-948

Posch T, Loferer-Krößbacher M, Gao G, Alfreider A, Pernthaler J, Psenner R (2001) Precision of bacterioplankton biomass determination: a comparison of two fluorescent dyes, and of allometric and linear volume-to-carbon conversion factors. Aquat Microb Ecol 25:55-63

Posch T, Franzoi J, Prader M, Salcher MM (2009) New image analysis tool to study biomass and morphotypes of three major bacterio plankton groups in an alpine lake. Aquat Microb Ecol $54: 113-126$
Quinones RA, Platt T, Rodríguez J (2003) Patterns of biomass-size spectra from oligotrophic waters of the Northwest Atlantic. Prog Oceanogr 57:405-427

Racy F (2004) Aspectos numéricos, morfólogicos e morfométricos da comunidade bacteriana em diferentes escalas trófica e temporal, em reservatórios. Thesis UFSCar, 2005. p 63. CDD: 574.5222 (20a)

Racy F, Godinho ML, Regau-Seleghim MH, Bossolan NRS, Ferrari AC, Lucca JV (2005) Assessment of the applicability of morphological and size diversity indices to bacterial populations of reservoirs in different trophic states. Acta Limnol Bras 17: 395-408

Rassoulzadegan F, Sheldon RW (1986) Predator-prey interactions of nanozooplankton and bacteria in an oligotrophic marine environment. Limnol Oceanogr 31:1010-1021

Reinthaler T, Van Aken H, Veth C, Arr'stegui J, Robinson C, Williams PJleB, Lebaron P, Herndl GJ (2006) Prokaryotic respiration and production in the meso and bathypelagic realm of the eastern and western North Atlantic Basin. Limnol Oceanogr $51: 1262-1273$

Robarts RD, Zohary T, Waiser MJ, Yacobi YZ (1996) Bacterial abundance, biomass, and production in relation to phytoplankton biomass in the Levantine Basin of the Southeastern Mediterranean Sea. Mar Ecol Progr Ser 137:273-281

Robinson AR, Leslie WG, Theocharis A, Lascaratos A (2001) Mediterranean Sea circulation. In: Steele JH, Turekian KK, Thorpe SA (eds) Encyclopedia of Ocean Sciences. Academic Press, London, pp 1689-1706

Santinelli C, Nannicini L, Seritti A (2010) DOC dynamics in the meso and bathypelagic layers of the Mediterranean Sea. Deep-Sea Res II $57: 1446-1459$

Scharek R, Latasa M (2007) Growth, grazing and carbon flux of high and low nucleic acid bacteria differ in surface and deep chlorophyll maximum layers in the NW Mediterranean Sea. Aquat Microb Ecol 46:153-161

Sempéré R, Yoro SC, Van Wambeke F, Charrière B (2000) Microbial decomposition of large organic particles in the northwestern Mediterranean Sea: an experimental approach. Mar Ecol Prog Ser 198:61-72

Simek K, Pernthaler J, Weinbauer MG, Hornàk K, Dolan JR, Nedoma J, Mašin M, Amann R (2001) Changes in bacterial community composition and dynamics and viral mortality rates associated with enhanced flagellate grazing in a mesoeutrophic reservoir. Appl Environ Microbiol 67:2723-2733

Tamburini C, Garel M, Al Ali B, Mérigot B, Kriwy P, Charrière B, Budillon G (2009) Distribution and activity of prokaryotes in the water column of the Tyrrhenian Sea. Deep-Sea Res II 56:700 712

Tanaka T (2009) Structure and function of the mesopelagic microbial loop in the NW Mediterranean Sea. Aquat Microb Ecol 57:351362

Tanaka T, Rassoulzadegan F (2002) Full-depth profile (0-2000 m) of bacteria, heterotrophic nanoflagellates and ciliates in the NW Mediterranean Sea: vertical partitioning of microbial trophic structures. Deep-Sea Res II 49:2093-2107

Van Wambeke F, Catala P, Lebaron P (2010) Relationships between cytometric characteristics of high and low nucleic-acid bacterioplankton cells, bacterial production and environmental parameters along a longitudinal gradient across the Mediterranean Sea. Biogeosciences Discuss 7: 8245-8279. doi:10.5194/ bgd-7-8245-2010. http://www.biogeosciences-discuss.net/7/8245/ 2010/

Vrede K, Heldal M, Norland S, Bratbak G (2002) Elemental composition $(\mathrm{C}, \mathrm{N}, \mathrm{P})$ and cell volume of exponentially growing and nutrient-limited bacterioplankton. Appl Environ Microbiol 68:2965-2971 
Williams PM, Carlucci AF (1976) Bacterial utilization of organic matter in the deep sea. Nature 262:810-811

Young KD (2006) The selective value of bacterial shape. Microbiol Mol Biol Rev. 660-703

Zaccone R, La Ferla R, Azzaro M, Caruso G (2002) Microbial parameters for advanced ecosystem models. Elsevier Oceanogr Ser 66:517-524. doi:10.1016/S0422-9894(02)80058-7

Zaccone R, Caroppo C, La Ferla R, Zampino D, Caruso G, Leonardi M, Maimone G, Azzaro M, Sitran R (2004) Deep-chlorophyll maximum time series in the Augusta Gulf (Ionian Sea): microbial community structures and functions. Chem Ecol 20: 267-284

Zaccone R, Boldrin A, Caruso G, La Ferla R, Maimone G, Santinelli C, Turchetto M (2012) Enzymatic activities and prokaryotic abundance in relation to organic matter along a West-East Mediterranean transect (TRANSMED cruise). Microb Ecol. doi:10.1007/s00248-012-0011-4

Żmuda MJ (2005) Abundance and morphotypes diversity of surface bacterioplankton along the Gdynia-Brest transect. Oceanol Hydrobiol Studies 34(4):3-17 